Afiifah, D. · W. Sutari $\cdot$ Kusumiyati $\cdot$ E. Suminar $\cdot$ S. Mubarok

\title{
Efektifitas 1-Methylcyclopropene (1-MCP) terhadap ketahanan simpan bunga potong mawar (Rosa hybrida hort.)
}

\section{The effectiveness of 1-Methylcyclopropene (1-MCP) on the flower longevity of cut rose (Rosa hybrida hort.).}

Diterima : 15 Februari 2017/Disetujui : 15 Maret 2017 / Dipublikasikan : 30 Maret 2017

CDepartment of Crop Science, Padjadjaran University

\begin{abstract}
Rose (Rosa hybrida Hort.) is one of popular ornamental plants and lot of interest among the public. But, one of problems often cut roses is short of flower longitivity. The purpose of this experiment is to obtain the optium concentration of 1-MCP and time of 1-MCP incubation in maintaining the freshness of cut roses. This experiment was conducted in Horticulture Laboratory Padjadjaran University on December 2016 with Completely Randomized Design of 7 treatments and repeated were: control (without 1-MCP), 1-MCP application $0.1,0.5$, and $1 \mu \mathrm{L} \mathrm{L}-1$ for 6 hours application, 0.1, 0.5, and 1 for 24 hours for application. The result showed that 1-MCP application for 24 hours gave the best result in maintaining the vase live cut flower to 9.67 days.
\end{abstract}

Keywords: Vase life - Cut flowers white roses cv. Avalance $\cdot 1-\mathrm{MCP}$

Sari Mawar (Rosa hybrida Hort.) merupakan salah satu tanaman hias yang populer dan banyak diminati di kalangan masyarakat. Namun, salah satu permasalahan yang sering dialami oleh produsen dan konsumen mawar adalah daya simpan nya yang cukup singkat. Tujuan dari percobaan ini adalah untuk mendapatkan konsentrasi 1-MCP serta lama aplikasi yang tepat dalam mempertahankan kesegaran bunga mawar potong. Percobaan dilaksanakan di Laboratorium Hortikultura Universitas Padjadjaran pada bulan Desember 2016 dengan menggunakan Rancangan Acak

Dikomunikasikan oleh Santi Rosniawaty

Afiifah, $\mathrm{D}^{1} \cdot$ W. Sutari ${ }^{2} \cdot$ Kusumiyati $^{2} \cdot$ E. Suminar ${ }^{2} \cdot \mathrm{S}$.

Mubarok $^{2}$

${ }^{1}$ Mahasiswa Program Studi Agroteknologi, Fakultas

Pertanian, Unpad

2Departemen Budidaya, Fakultas Pertanian, Unpad

Korespondensi: syariful.mubarok@unpad.ac.id
Lengkap pola Sederhana dari tujuh perlakuan yaitu kontrol, pemberian 1-MCP 0.1, 0.5, dan 1 $\mu \mathrm{L} \mathrm{L}^{-1}$ yang diberikan selama 6 jam, serta 0.1, 0.5, dan $1 \mu \mathrm{L} \mathrm{L}^{-1}$ yang diberikan selama 24 jam. Hasil percobaan menunjukkan bahwa aplikasi 1 $\mu \mathrm{L} \mathrm{L}^{-1} 1$-MCP selama 24 jam memberikan hasil terbaik dengan mempertahankan lama segar bunga potong mawar cv Avalance putih selama 9.67 hari.

Kata kunci: Lama kesegaran • Bunga potong mawar cv. Avalance putih $\cdot 1-\mathrm{MCP}$

\section{Pendahuluan}

Mawar (Rosa hybrida Hort.) merupakan salah satu tanaman hias yang populer dan banyak diminati di kalangan masyarakat. Mawar potong sering digunakan untuk kegiatan keagamaan, acara pernikahan, syukuran dan acara lainnya (Tejasarwana dan Rahardjo, 2009). Beragam kegunaan dari bunga ini memperlihatkan bahwa bunga mawar memiliki nilai ekonomi dan sosial yang tinggi sehingga bunga ini memiliki prospek yang cukup baik apabila dikembangkan dan dijadikan komoditas perdagangan. Permasalahan yang sering dialami oleh produsen maupun konsumen bunga potong, khususnya bunga mawar adalah lamanya daya simpan bunga yang sangat singkat. Umumnya, setelah panen, mawar memiliki masa kesegaran selama 4-5 hari (Nofriati, 2005). Singkatnya masa segar bunga merupakan kendala utama produk bunga potong yang menyebabkan lama waktu simpan sangat singkat.

Penurunan kualitas setelah panen tidak dapat dihindari karena hasil panen mendapatkan bahan respirasi dan transpirasi hanya dari bagian yang telah dipanen. Namun, 
penurunan kualitas dapat diperlambat dengan penanganan pasca panen yang tepat, salah satunya adalah dengan pemberian senyawa kimia. Salah satu bahan kimia yang sudah sering digunakan dalam pengawetan bunga potong adalah 1-methylcyclopropene (1-MCP).

1-MCP sudah sering digunakan pada komoditas hortikultura untuk menghambat efek dari etilen dalam meningkatkan ketahanan simpan pasca panen, seperti pada tanaman tomat (Moretti et al., 2002). Akan tetapi konsentrasi optimum 1-MCP untuk setiap tanaman tersebut berbeda-beda. Kebutuhan bunga terhadap 1-MCP berbeda-beda tergantung dari stadia bunga tersebut. Menurut Sisler et al., (1996), bunga carnation yang tua membutuhkan 1-MCP dengan konsentrasi yang lebih tinggi untuk mempertahankan masa hidupnya. Dengan melihat efeknya penggunaan 1-MCP untuk meningkatkan ketahanan simpan beberapa komoditas hortikultura, maka dalam percobaan ini akan dicoba penggunaan 1-MCP pada bunga mawar potong dengan harapan diperolehnya konsentrasi optimum untuk setiap stadia pertumbuhan bunga, yang pada akhirnya dapat dijadikan acuan penanganan pasca panen mawar Rosa hybrida.

\section{Bahan dan Metode}

Percobaan dilaksanakan di Laboratorium Hortikultura Fakultas Pertanian Universitas Padjadjaran, Jatinangor, Kabupaten Sumedang. Bahan tanaman yang digunakan adalah bunga mawar potong cv. Avalanche putih yang masih kuncup dan didapatkan dari petani mawar Cihideung dengan pangjang tangkai $50 \mathrm{~cm}$. Bahan lain yang digunakan adalah serbuk 1MCP dengan beberapa konsentrasi yang berbeda, kertas tissu, dan air. Alat yang digunakan adalah ruang kaca kedap udara dengan volume $60 \mathrm{~L}$, botol kaca bekas, gelas ukur, dan alat tulis.

Penelitian ini menggunakan Rancangan Acak Lengkap (RAL) sederhana dengan tujuh perlakuan yang diulang sebanyak tiga kali sehingga terdapat 21 plot percobaan. Setiap plot percobaan terdiri dari satu tangkai bunga potong mawar. Rancangan perlakuan 1-MCP terdiri dari:

A: $0 \mu L^{-1} 1-M C P$ (kontrol)

B: $0.1 \mu L^{-1} 1$-MCP selama 6 jam

C: $0.5 \mu \mathrm{L} \mathrm{L}^{-1} 1$-MCP selama 6 jam
D: $1 \mu \mathrm{L} \mathrm{L}^{-1} 1$-MCP selama 6 jam

E: $0.1 \mu \mathrm{L} \mathrm{L}^{-1} 1-\mathrm{MCP}$ selama 24 jam

F: $0.5 \mu \mathrm{L} \mathrm{L}^{-1} 1$-MCP selama 24 jam

G: $1 \mu \mathrm{L} \mathrm{L}^{-1} 1-\mathrm{MCP}$ selama 24 jam.

Ujung tangkai bunga diberi kertas tissu yang sudah dibasahi untuk menjaga kesegaran bunga selama aplikasi 1-MCP kemudian disimpan dalam ruang kaca kedap udara. Sebelum ditutup, 1-MCP berbagai konsentrasi dalam wadah kecil dimasukkan ke dalam ruang kaca tersebut kemudian diberi beberapa tetes air. Ruang kaca ditutup dan setiap ujungnya dilapisi solatip untuk menghindari adanya udara yang keluar atau masuk. Setelah 6 dan 24 jam, bunga di keluarkan dan disimpan dalam botol kaca yang telah berisi $500 \mathrm{~mL}$ air.

\section{Hasil dan Pembahasan}

1-MCP merupakan senyawa volatil yang dapat menghambat aktivitas etilen (Ichimura et al., 2002). Menurut Enviromental Protection Agency (2002), 1-MCP sering digunakan pada komoditas hortikultura karena senyawa ini tidak bersifat racun. Penggunaan 1-MCP sebaiknya dengan konsentrasi sekecil mungkin, yang tentunya harus dikombinasikan dengan waktu yang lebih lama sehingga dapat menghemat biaya (Setyadjit et al., 2012).

Lama Kesegaran Bunga (hari). Hasil analisis aplikasi 1-MCP dengan beberapa konsentrasi dan lama inkubasi sebagaimana disajikan pada gambar 1 menunjukkan bahwa aplikasi 1-MCP dapat mempertahankan kesegaran bunga mawar potong cv. Avalance. Hal tersebut diduga karena 1-MCP mengikat reseptor etilen. Konsentrasi 1-MCP harus tepat untuk memenuhi reseptor dan perlakuan harus pada waktu yang cukup lama agar gas menembus jaringan tanaman (Blankenship, 2001).

Berdasarkan gambar 1 , pemberian $1 \mu \mathrm{L} \mathrm{L}^{-1} 1$ MCP selama 24 jam (perlakuan G) mem-berikan hasil terbaik dengan mempertahankan kesegaran bunga paling lama. Namun hasil tersebut tidak berbeda nyata dengan pemberian 1-MCP dengan durasi aplikasi yang sama lainnya (perlakuan E dan F). Hal ini membuktikan bahwa semakin lama waktu aplikasi 1-MCP, semakin lama juga efektifitas 1-MCP dalam mempertahankan vase live bunga mawar potong. Sehingga, pada gambar 1 menunjukkan bahwa aplikasi $1 \mu \mathrm{L} \mathrm{L}^{-1} 1-\mathrm{MCP}$ selama 24 jam dapat mempertahankan vase life bunga $70.55 \%$ lebih lama daripada tanpa aplikasi 1-MCP. 


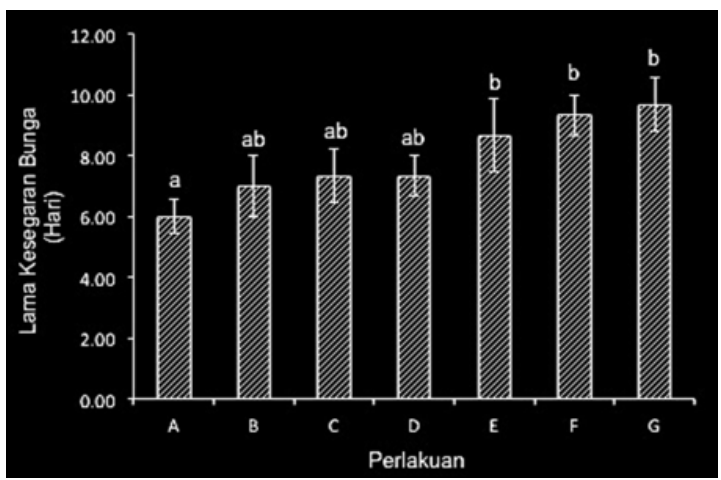

Gambar 1. Pengaruh kombinasi konsentrasi dan durasi pemberian 1-MCP terhadap lama kesegaran bunga mawar potong (hari). Nilai rata-rata \pm SE yang diikuti oleh huruf yang sama tidak berbeda nyata menurut Uji Duncan pada taraf 5\%

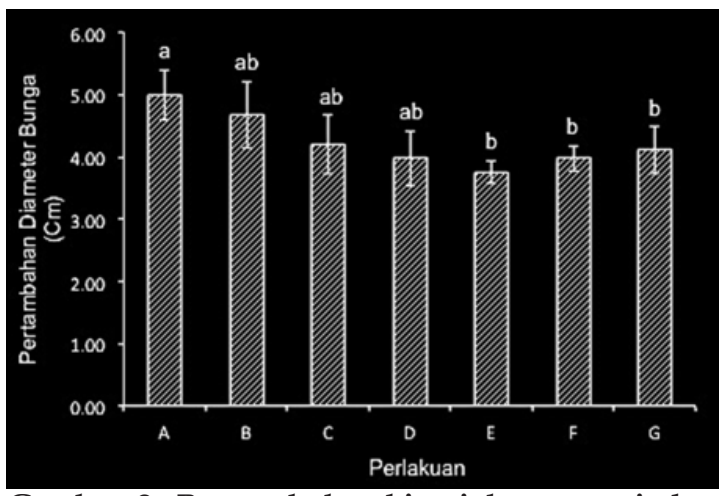

Gambar 2. Pengaruh kombinasi konsentrasi dan durasi pemberian 1-MCP terhadap pertambahan diemater bunga mawar potong. Nilai rata-rata $\pm \mathrm{SE}$ yang diikuti oleh huruf yang sama tidak berbeda nyata menurut Uji Duncan pada taraf 5\%.

Ekspresi gen untuk reseptor etilen meningkat dengan penuaan bunga pada beberapa tanaman seperti tomat (Payton et al., 1996) dan kacang polong (Orzaez et al., 1999). Hal tersebut menimbulkan kemungkinan bahwa reseptor etilen tetap tersintesis selama penuaan bunga. Maka, diduga reseptor etilen yang telah terikat oleh 1-MCP mungkin tergantikan oleh sintesis reseptor yang baru dan reseptor tersebut dapat terikat oleh etilen kembali (Ichimura et al., 2002). Hal tersebut yang menyebabkan bunga tetap layu.

Pertambahan Diameter Bunga (cm). Dari Gambar 2 terlihat bahwa perlakuan A (kontrol) paling cepat mengalami pertambahan diameter. Sedangkan perlakuan yang dapat memper-lambat pertambahan diameter bunga adalah perlakuan $\mathrm{E}$ (0.1 $\mu \mathrm{L} \mathrm{L}^{-1} 1$-MCP selama 24 jam), namun tidak berbeda nyata dengan perlakuan $F$ dan $G$. Hal tersebut membuktikan bahwa pemberian 1-MCP mampu memperlambat pertambahan diameter bunga. Sejalan dengan hasil percobaan AitOubahou et al (2003) bahwa 1-MCP mampu mempertahankan berat bunga, diameter, dan vase life bunga potong mawar 'Marlyse'.

Sudut Kulai Bunga ( ${ }^{\circ}$. Salah satu syarat mutu bunga potong mawar yaitu kuntum yang tegak. Maka dari itu, setiap kuntum yang mulai membengkok sudah mengalami penurunan kualitas. Secara visual, pelayuan bunga ditandai dengan pelayuan mahkota bunga, meningkatnya sudut kulai bunga dan juga pelayuan dari bunga cakramnya (Suradinata, 2012).

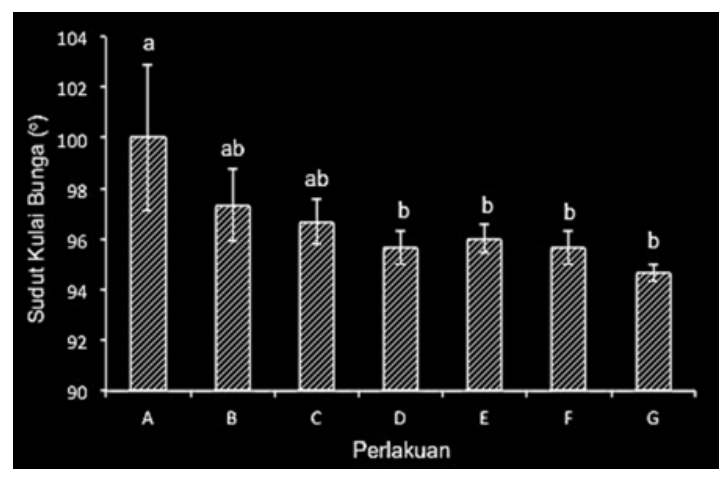

Gambar 3. Pengaruh kombinasi konsentrasi dan durasi pemberian 1-MCP terhadap sudut kulai bunga mawar potong. Nilai rata-rata \pm SE yang diikuti oleh huruf yang sama tidak berbeda nyata menurut Uji Duncan pada taraf 5\%.

Gambar 3 menunjukkan bahwa pemberian $1 \mu \mathrm{L} \mathrm{L}^{-1}$ 1-MCP selama 24 jam (perlakuan $\mathrm{G}$ ) mampu memperlambat kulai bunga. Namun hasil tersebut tidak berbeda nyata dengan pemberian $1 \mu \mathrm{L} \quad \mathrm{L}^{-1} \quad 1-\mathrm{MCP}$ selama 6 jam (perlakuan D), serta pemberian 0,1 dan $0,5 \mu \mathrm{L} \mathrm{L}^{-1}$ 1-MCP selama 24 jam. Hasil tersebut sangat berbeda nyata dengan perlakuan A (kontrol) yang menunjukkan perubahan sudut kulai bunga yang sangat cepat.

Skor Kelayakan Bunga. Skoring dilakukan untuk melihat perubahan yang terjadi selama penyimpanan. Perubahan tersebut dapat berupa perubahan warna bunga, rontoknya daun, rontoknya kelopak bunga, dan perubahan diameter bunga atau stadia kemekaran bunga.

Pada perlakuan tanpa 1-MCP skor kelayakan bunga dari 1 HSP sampai 5 HSP mengalami peningkatan skor yang paling cepat. Sedangkan aplikasi $0.5 \mu \mathrm{L} \mathrm{L}^{-1}$ dan $1 \mu \mathrm{L} \mathrm{L}^{-1} 1$ MCP selama 24 jam mengalami peningkatan skor yang paling lambat. Berdasarkan Gambar 4, pemberian 1-MCP dapat menekan kerusakan 
bunga potong mawar cv Avalance putih selama penyimpanan.

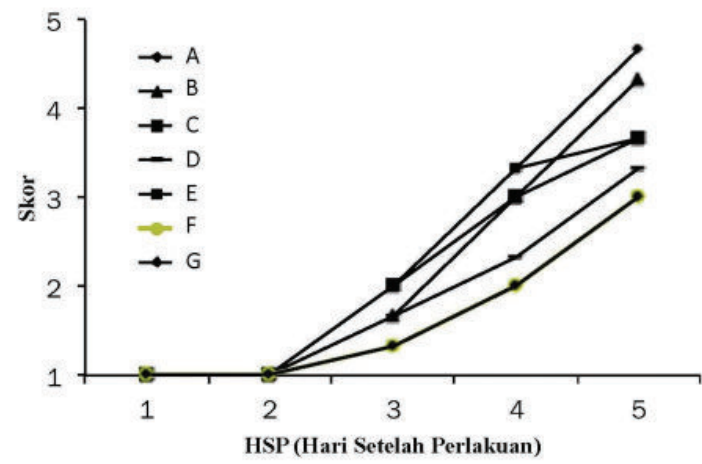

Gambar 4. Perubahan skor kelayakan bunga potong mawar cv. Avalance putih

Keterangan:

Skor: 1 . Bunga segar; 2 . Bunga $3 / 4$ mekar; 3 . Bunga mekar sempurna, daun mulai rontok; 4. Daun mulai rontok, bunga mulai kulai; 5. Bunga kulai / kelopak bunga rontok / browning

Kerusakan yang terjadi pada percobaan ini berupa perubahan warna bunga menjadi pudar, browning, dan sudut kulai bunga $>130^{\circ}$. Salah satu persyaratan umum dari bunga potong mawar menurut Badan Standar Nasional Indonesia (2016) adalah memiliki daun 2/3 panjang tangkai lengkap dan sehat. Sehingga, apabila daun tidak memenuhi syarat maka dapat disebut bahwa bunga tersebut mengalami penurunan kualitas.

Pada konsentrasi 0,25 $\mu \mathrm{L} \mathrm{L-1,1-MCP} \mathrm{sudah}$ mampu menghambat perubahan warna bunga, mencegah pelayuan bunga dan mempertahankan kesegaran bunga krisan potong 'Yellow Fiji' (Mubarok, 2012). Hasil penelitian Hasan dan Ali (2014), menunjukkan bahwa aplikasi 1-MCP pada bunga gladiol dapat memperlambat laju penurunan berat segar bunga, kandungan air, kandungan klorofil pada daun gladiol, persentase karbohidrat pada daun gladiol, dan produksi etilen pada bunga gladiol.

Proses kelayuan dipengaruhi oleh adanya etilen. Menurut Salsabila dan Juang (2013), bunga yang memiliki vase life yang lebih lama diduga memiliki kemampuan memproduksi etilen yang rendah dalam proses metabolismenya. Etilen juga dapat menyebabkan bunga mawar kultivar "Royalty" mekar seperti bintang (Reid et al., 1988). Konsentrasi etilen yang rendah, sudah mampu mempercepat mekarnya beberapa kultivar mawar. Menurut Ella et al. (2003), etilen menyebabkan degradasi klorofil sehingga daun cepat mengalami penuaan.

\section{Kesimpulan dan Saran}

Berdasarkan hasil percobaan, dapat diambil kesimpulan sebagai berikut:

1. Aplikasi $1 \mu \mathrm{L} \mathrm{L} \mathrm{L}^{-1}$ 1-MCP selama 24 jam mampu mempertahankan kesegaran bunga mawar potong cv. Avalance putih $70.55 \%$ lebih lama (9.67 hari) daripada tanpa 1-MCP (5.67 hari).

2. Aplikasi 0.5 dan $1 \mu \mathrm{L} \mathrm{L}^{-1}$ 1-MCP selama 24 jam mampu memperlambat laju kerusakan bunga potong mawar cv. Avalance putih.

\section{Daftar Pustaka}

Ait-Oubahou, A. Mokhtari, M. and El-Mellouki, A. 2003. Effect of 1-MCP on the quality and vase life of cut roses cv. 'Marlyse'. p. 408411. In: M. Vendrell, H. Klee, J.C. Pech and F. Romojaro (eds.), Biology and Biotechnology of the Plant Hormone Ethylene III. IOS Press, Amsterdam.

Badan Standar Nasional Indonesia. 2016. Standar nasional Indonesia mawar potong. SNI 4492

Blankenship, S. 2001. Ethylene effect and the benefits of 1-MCP. No.108. ucanr.edu diakses pada Kamis, 27 Oktober 2016

Ella, E.S., N. Kawano, Y. Yamauchi, K. Tanaka, A.M. Ismail. 2003. Blocking ethylene perception enhances flooding tolerance in rice seedlings. Funct. Plant Biol. 30:813-819

Enviromental Protection Agency. 2002. Biopesticide registration action document 1-methylcyclopropene. PC Code 224459

Hassan, F.A.S. dan E. Ali. 2014. Physiologycal response of gladiolus flowers to antiethylene treatments and their relation to senescence. International Journal of Advanced Research. Vol.2(10). P: 188-199

Ichimura, K. S. Hiroko., and H. Toshihiko. 2002. Effect of 1-methylcyclopropene (1-MCP) on the vase life of cut carnation, Delphinium and sweet pea flowers. Bull. Natl. Inst. Flor. Sci. 2: $1-8$

Moretti, C.L. Alessandra, L.A. Waldir, A.M. Washington, L.L.Silva. 2002. 1Methylcyclopropene delays tomato fruit 
ripening. Horticultura Brasileira.Vol.20(4): 659-663

Mubarok, S. 2012. Kualitas bunga krisan potong 'Yellow Fiji' sebagai respon dari aplikasi 1Methylcyclopropene. J.Agrivigor. Vol.11(2). P:244-250

Nofriati, D. 2005. Kajian sistem pengemasan bunga mawar potong (Rosa hybrida) selama penyimpanan untuk memperpanjang masa pajangan. Bogor

Orzaez, D. R. Blay. dan A., Granell. 1999. Programme of senescence in petals and carpets of Pisum satioum L. flowers and its control by ethylene. Planta. Vol.208: 220-226

Payton, S. R.G. Fray. S.Brown. dan D. Grierson. 1996. Ethylene receptor expression is regulated during fruit ripening, flower senescence and abscission. Plant Mol. Biol. 31:1227-1231

Reid, M.S. Linda, L. D. Yoram, M. Richard, Y. E. 1988. Effects of ethylene on rose opening. These Proceedings
Salsabila, Ilsa dan Juang, G. Kartika. 2013. Aplikasi 1-Methylcyclopropene untuk meningkatkan vase life bunga potong Tapeinochilos anannaceae K.Schum. Bul. Agrohorti. Vol 1(4).P: 101-110

Setyadjit. Ermi, Sukasih. dan Asep, W. Permana. 2012. Aplikasi 1-MCP dapat memperpanjang umur segar komoditas hortikultura. Bul. Teknol. Pascapanen Pertanian. Vol.8(1): 27-34

Sisler, E. C. E. Dupille. dan M, Serek. 1996. Effect of 1-methylcyclopopene and methylenecyclopropane on ethylene binding and ethylene action on cut carnation. Plant Growth Regul. 18: 79-86

Suradinata, Y.Rochayat. 2012. Penggunaan benzyl amino purine (BAP) untuk meningkatkan kesegaran bunga krisan. J.Agrivigor. Vol. 11(2): 223-229

Tejasarwana, R. dan I.B. Rahardjo. 2009. Pengaruh formula pupuk dan jarak tanam terhadap hasil dan kualitas bunga mawar potong. J.Hort. Vol. 19(3). P: 287-293 